\title{
THE ESSENCE OF REMUNERATION FEASIBILITY IN AN EFFORT FOR THE WELFARE OF THE WORKER
}

\author{
Zulkarnain Ibrahim \\ Faculty of Law, Sriwijaya University \\ E-mail: zulibrahim007@gmail.com
}

\begin{abstract}
The Remuneration feasibility is one of workers' fundamental principle, must be implemented in national development program on employment by setting policy of composing planning labor, employment information, and job training. Professional workers will increase the productivity and company profit. Positive impact to workers, will receive their right for reasonable wages, so that reached welfare for them and their family, and live honorably and dignified in society.
\end{abstract}

Keywords: law, workers, reasonable wages

\begin{abstract}
Abstrak
Asas kelayakan pengupahan merupakan salah satu asas fundamental pekerja, harus diimplementasikan dalam program pembangunan nasional di bidang ketenagakerjaan dengan menetapkan kebijakan menyusun Perencanaan Tenaga Kerja, Informasi Ketenagakerjaan, dan Pelatihan Kerja. Pekerja yang profesional, akan meningkatkan produktivitas dan keuntungan perusahaan. Dampak positip bagi pekerja, akan menerima haknya atas upah layak, sehingga tercapai kesejahteraan diri dan keluarganya serta hidup terhormat dan bermartabat dalam masyarakat.
\end{abstract}

Kata kunci: hukum, pekerja, upah layak

\section{Introduction}

Unemployment and poverty became the driving force for most of citizens to work anywhere, including abroad. According to Connie de la Vega and Conchita Lazaro-Batista, the number of migrant workers around the world will increase rapidly as long as the home country can not providing jobs and a decent wage. Besides, in other countries provide a variety of jobs with higher wages than their home country. ${ }^{1}$ It means that labor mobility will give an impact on the quantity, quality and the range of wages in a country.

Low quality of labor will affect to the low of bargaining position between the workers and entrepreneurs in labor relations system, includ-

Sefriani, "Perlindungan HAM Buruh Migran tak berdokumen Berdasarkan Hukum Perdagangan dan Hukum HAM Internasional” Jurnal Dinamika Hukum, Vol. 13, No. 2, Mei 2013, Purwokerto: Fakultas Hukum Universitas Jenderal Soedirman, hlm. 245. Lihat: Connie de la Vega dan Conchita Lazaro-Batista, "Advocates Should use Applicable Internatioanl Standard to Adress Violation of Undocumented Migran Workers Rihgts in The United States", 3 ing in terms of wages. Low quality labor can be known when we will compare the readiness of Indonesian workers to compete with foreign workers that seeking employment in Indonesia. The comparison types such as: first, the level of education; second, skills; third restrictions on employment opportunities; fourth, the view that foreign workers have a higher quality than local workers; and fifth, Scarcity of Workers with the appropriate quality needs. ${ }^{2}$ This comparisons become a reference condition for Indonesia with other countries in terms of wages.

Normatively, Article 27 paragraph (2) of the 1945 Constitution states that: "Every citizen has the right to work and a decent living for humanity". As for Article 88 paragraph (1) of Law

Hasting Race and Poverty Law Journal 35, Tahun 2005, $\mathrm{h} / \mathrm{m} .36$.

2 Frankiano B. Randang, "Kesiapan Tenaga Kerja Indonesia dalam Persaingan dengan Tenaga Kerja Asing", Jurnal Ilmiah Hukum Servanda, Vol. 5, No. 1, Januari 2011, Manado: Fakultas Hukum Universitas Katolik De La Salle, $\mathrm{hlm}$ 69-71. 
Number 13 of 2003 on Manpower (Manpower Law) states that "every worker has a right to earn to fulfill a decent life for humanity". ${ }^{3}$ On the basic of these rules, the worker conditions should be better.

Nowadays, the conditions of employment in Indonesia tend to only impose a wage policy that is just procedural not substantive justice. The procedural justice is caused by the policy of Provincial Minimum Wage (Upah Minimum Provinsi, UMP) from the government. UMP is intended only as a safety net for the weak company in terms of profit, not for strong compa-nies or the great taxpayers (income tax). ${ }^{4}$

Problems of employers to pay decent wages is not matched by a proffesionality and high productivity of Indonesian workers. Data from Aviliani about unskilled labor can be seen in the table below. ${ }^{5}$

Table 1. Low Skill

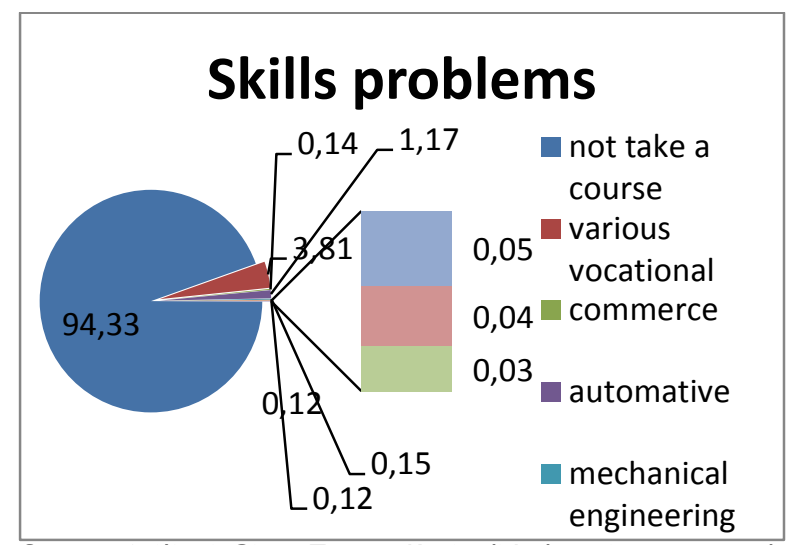

Source: Aviliani, Biaya Tenaga Kerja di Indonesia, presented at Forum Konsolidasi Dewan Pengupahan se Indonesia, Jakarta, 3-5 September 2013.

The explanation of that table about skilled labor only reached 5.67 percent, while the unskilled labor because they do not follow the courses of skills reached 94.33 percent. According to the writer, the amount of unskilled labor, because: first, live in rural areas, they are not

3 Zulkarnain Ibrahim, "Eksistensi Hukum Pengupahan Yang Layak Berdasarkan Keadilan Substantif”, Jurnal Dinamika Hukum, Vol. 1, No. 3, September 2013, Purwokerto: Faculty of law Universitas Jenderal Soedirman, page. 526.

4 Zulkarnain Ibrahim, "Pengaturan dan Penegakan Hukum, Pengupahan", Jurnal Hukum lus Quia lustum", Vol. 22, No. 4, October 2015, Yokyakarta: Faculty of Law Universitas Islam Indonesia, page. 653-654.

$5 \quad$ Ibid, page. 661. covered by skills course; second, skills course is expensive; third, Training Center (BLK) is in the provincial capital; ${ }^{6}$ and fourth, high school graduates students more choose bachelor programs than the vocational diploma program.

For workers, decent wages problem is a sensitive issue and implicating to the dispute. The emergence of the dispute caused by the indication of a violation to the legal principles of wage which include appropriateness wage principles, the principle of no work no pay, the principle of social risk and the principle of equal pay equal job. In this paper, the object discussion of wage is a key point that must be given a solution in order to get substantive jus-tice through the principle of appropriateness wage as set in a Labor Law.

\section{Discussion}

Sudikno Mertokusumo stated that the rights and obligations is not a set of rules or nor$\mathrm{ms}$, but the balance of power in the form of individual rights on the one hand reflected in the obligation on the opposing side. Rights and obligations is an authority that given to a person by law. ${ }^{7}$ However, in implementing its rights and obligations should provide protection and justice for all parties.

Workers protection, is one of the goals of substantive justice, in addition to farmers, fishermen and small traders. Justice for the poor people is reflect the understanding about the lack approachment that oriented to people needs. Government urged to reform the labor law enforcement, for social justice and the welfare of workers. ${ }^{8}$

Essentially, the protection of labour laws should be represented by the country against the weak side. State must provide legal assistance to the citizens in an effort and as the implemen-

Ibid

Ari Hernawan, "Keseimbangan Hak dan Kewajiaban Pekerja dan Pengusaha dalam MogokKerja", Jurnal Mimbar Hukum, Vol. 24, No. 3, October 2012, Yogyakarta: Faculty of Law UGM, page. 419.

8 Zulkarnain Ibrahim, "Sejarah Hukum Ketenagakerjaan: Studi terhadap Pasang Surutnya Keadilan Sosial Pekerja”, Jurnal Simbur Cahaya, Vol. XX, No. 51, May 2013, Palembang: Faculty of Law Universitas Sriwijaya, page. 3542. 
tation of state laws that recognize, protect and guarantee the human rights of its citizens access for justice and equality in the law. ${ }^{9}$ In the implementation, workers must also comply with the economic law that based on supply and demand balance. The meeting between demand and supply is creating the implications as the agreement for the existence of rights and obligations between employment and wages.

It has been set in the rules regarding the protection of the workers rights to prevent an unlawful act. ${ }^{10}$ Right to work and the rights in the work not only as a social and economic rights, but also a fundamental human rights in the system of labor relations. ${ }^{11}$

The fundamental human rights should be in line with the principle of appropriateness of wage in order to make workers have prosperious life with their family. The principle of appropriateness of wage in the 1945 constitution and Labour Legislation must be implemented in national development programs to be done at the company level.

Legal protection for workers is a manifestation of the effort to promote the general welfare, educating the nation. However, the basic philosophy set by the makers of Labour Law did not provide extensive and comprehensive meaning as set in the 1945 Constitution. This is evident in the consideration of letter D Labor Law that "The protection of labor is intended to guarantee the basic rights of workers/laborers and ensure the equality of opportunity and treatment without discrimination on any ground for the welfare of workers/laborers and their families regard to the progress of the business world". ${ }^{12}$ As according to Article 4 of the Labour Law states that labor development aims to: first, empower and utilize manpower optimally

$9 \quad$ Atik Krustiyati, "Optimalisasi Perlindungan dan Bantuan HukumPekerja Migranmelalui Promosi Konvensi Pekerja Migran Tahun 2000”, Jurnal Dinamika Hukum, Vol. 13, No. 1, January 2013, Purwokerto: Faculty of Law Universitas Soedirman, page. 146.

10 Okky Chahyo Nugroho, "Kajian Atas Kasus-Kasus Pelanggaran HAM TKW di Luar Negeri”, Jurnal HAM, Vol. 3 No. 2, December 2012, Jakarta: Kementerian Hukum dan HAM, page. 84.

11 Ujang Charda S, "Perlindungan Hukum Ketenagakerjaan Terhadap Tenaga Kerja Anak yang Bekerja di luar Hubungan Kerja pada Bentuk Pekerjaan terburuk", Jurnal and humane; second, realize equal employment opportunities and providing manpower according to the needs of national and regional development; third, provide protection to workers for welfare; and fourth, improve the welfare of workers and their families. ${ }^{13}$

Basically, the efforts for equal employment opportunities must be done in all parts of Indonesia, therefore, the Local Governments should strive to invite national and foreign investors to invest in those area. As the attraction for investors, certainly the regional government set up the ease of licensing and infrastructure, such as roads, electricity, telecommunications, water, ports and so on. When compared with the best practices in Japan, before 2006, there is so many companies in Japan established the company's location closer to the market. But after 2006, the company was set up in rural areas. In this case, the company strives to provi-de benefits to workers and facilitate rural labor to get the job. ${ }^{14}$ Company standing policy in the rural area give an impact such as: first, cost of living is cheaper than the big cities in Japan; second, minimize urban workers from the rural; third, equaly welfare level; and fourth, transfer the technology from the city to the rural area.

In the United States, the policy taken is perform the empowerment and workforce optimally through surveillance systems. Supervision for workers productivity can be done by using the technology that can monitoring the workers activities. Throughout the United States and most industrialized countries, businessmen buy and implement great and new technologies that can improve security and monitoring worker productivity. The result is, the productivity of workers increase than before using the

Syiar, Vol . XII, No. 2, Edition July 2010, Bandung: Faculty of Law UNISBA, page. 117.

12 St. Laksanto Utomo, "Permasalahan Outsourcing dalam Sistem Ketenagakerjaan di Indonesia", Jurnal Lex Publica, Vol. 1 No. 1, January 2014, Jakarta: Faculty of Law. Usahid, page.4.

13 Asri Wijayanti, 2009, Hukum Ketenagakerjaan Pasca Reformasi, Jakarta: Sinar Grafika, page.7.

14 Minoru Ito, "Measures for Supporting Regional Job Creation in Japan", Japan Labor Review, Vol. 5, No. 1, 2008, page. 95. 
surveillance technology. ${ }^{15}$ The increased of productivity also resulted an increase in wages for workers. Technology not only have a negative impact on the environment, but also to the social environment can be reduce the communication between the employers and workers.

Ultimately, policy changes in Japan and the United States aimed to improving the welfare of workers. While, in Indonesia through the effort to implement the principle appropriateness of wage, can modelled the good things from the other country by policies that favor to the welfare of workers.

Institutionally, the efforts to improve the welfare of workers can be done when the employers give priority to the welfare of the company, workers and the community around. Entrepreneurs efforts to improve the welfare of workers including such as: first, improving the quality and quantity of companies with modern management. This leads companies to use modern management work professionally and minimize the various action as "bad parties" that led to the ballooning expenses (high cost) of companies that are not productive.

Expenses or costs "stealth" which ranges $20-30 \%$ of the total cost of the company can be used to advance the company and pay the workers with decent wages. Workers wage that range about $8 \%$ of the total cost, will be increased to $16 \%$ or $24 \%$ of the total cost. It means that the wages can be increased to $200 \%$ or $300 \%$.

For example, the application of the applicable UMP in 2013 amounted to Rp. 1,400,000.for South Sumatra, with the application of modern management can be increased to $200 \%$ or $300 \%$, then the wage for the workers could be Rp. $2,800,000$. - or Rp. 4,200,000. -. This last wages can be a wage for fulfill the minimum needs for a decent life. ${ }^{16}$

Second, company should obey Labor Law, so it can: a) implementing its obligation to the labors by giving them decent wages, guarantee

15 William A. Herbert et al., "The Impact of Emerging Technologies in The Workplace : Who's Watching The Man (Who's Watching Me) ?", Law Journal, Hofstra Labor \& Employment, Vol. 25, 2009, page. 355. the work safety, following BPJS Labor(BPJS Ketenagakerjaan) and work situations which is compatible with its labor; and b) running the com-pany quietly, without worrying at some point will be examined by The Department of Manpower and Transmigration or Ministry of Manpower and Transmigration for violating Labor Laws.

In the future, efforts should be done by The Government to implement the eligibility principle of wage towards a decent wage, such as: Department of Manpower and Transmigration or Ministry of Manpower and Transmigration implement the Laws in the field of employments by: first, determine a policy and arrange labor planning; second, labor information; third; implement the job training.

Determination of policies and arrange labor planning is based on Article 7 of The Labor Law that government in sett-ing policy and arranging labor planning; and labor information; includes: first, macro labor planning; and second, micro labor planning. In arranging the policies, stragies, and the implementation of sustainable labor development program, government should be guided on labor planning. Article 8 of The Labor Law stated that labor planning arranged based on labor information, such as: 1) job training including job competence; and 2) labor productivity.

Job training regulated in Article 9; 10, 11, 12, and 13 of The Labor Law that: 1) work training organized and directed to supply, improve, and develop job competence to increase the capability, pro-ductivity, and prosperity; 2) work training carried out with the regard to labor market needs and business world, both inside and outside the work relationship. The implementation, based on the training program which refers to work competency standards and carried out in stages. 3 ) every worker has a right to get/or increase and/or develop job competence in accordance with their talents, inte-

16 Zulkarnain Ibrahim, "Hukum Pengupahan yang Berkeadilan Substantif (Kajian Teoritis Terhadap Teori Upah Teladan)", Jurnal Masalah-Masalah Hukum, Vol. 42 No 2, April 2013, Semarang: Faculty of Law Universitas Diponegoro, page 297-298. 
rests, and abilities through job training; and 4) entrepre-neurs have responsibility for improving and/or the development of their workers through job training. Every worker has the same opportunity to participate in job training which is suitable with their working field. In job training context, the substance is reinforced by Centre of Research, Development and Information Ministry of Manpower and Transmigration by preparing Academic Paper Employment Policy Directions or "Naskah Akademik Arah Kebijakan Ketenagakerjaan" Years 2014-2019 and coordinate with the entire region which have Training Centre or "Balai Latihan Kerja (BLK)" to make spesification of potential area as a basis for implementing the training work skill.

For that Ministry of Manpower and Transmigration and local government have to reorient, revitalization, and fulfillment capacity of BLK, by: first, adjusting instructor both the number and also the capabilities on every major through evaluation regularly every year based on DUK, in order to know instructor who will enter MPP and it may be filed Instructor Candidates recruits; second, fixing recruitments pattern of instructor candidates with the vocational-oriented comformity with fomal education; third, adjusting the equipment with BLK needs; fourth, increasing cooperation networks with other training institutions and company; fifth, increasing the implementation of Training Needs Assessment (TNA); sixth, carrying out promotion so BLK will be more well known and enthused by workers and companies, which is done routinely and regularly minimumly once in a year; and seventh, increasing skill and attitude the graduate of Ministry of Manpower and Transmigration BLK to be more profesional and can be human capital. ${ }^{17}$

Goverment has regulate about the wage in Articel 88 of The Labor Law, that "every worker has right to get income that meets the decent life for humanity. To actualize income that meets the decent life for humanity, the govern-

17 Pusat Penelitian, Pengembangan dan Informasi Kemenakertrans, 2013, Naskah Akademik Arah Kebijakan Ketenagakerjaan Tahun 2014-2019, Jakarta: Kemenakertrans, page 57 ment sets a wage policy that protects the workers." If we examine the content in Article 88 of The Labor Law regarding wages, it turns out that the substance is still absurd, because the details have not been technically regulate the wages. It is supposed to reformulate Article 88 of The Labor Law regarding wages to reach the standards of decent wage, with verses that support it.

Reformulation Article 88 (1) The Labor Law is every worker has right to get income that meets the decent life for humanity; Article 88 (2) is "The criteria of decent income, as follows: first, ilt is enough clothing, food and shelter; second, it is able to save a part of wages for health costs/education and social costs. ${ }^{18}$ Although Article 88 of The Labor Law reformulated, but in the future there should be constructive efforts held by Disnakertrans and Kemenakertransto achieve the principles of appropriateness of wages to create justice in order to create prosper workers.

Factually, in order to reach fairness in wages there are obtacles both internal and also external such as: first, internally there are obstacles in the form of the a) profesionality of Civilian State Apparatus or Aparatur Sipil Negara (ASN) is not optimal; b) limited budget; and c) the law enforcement is stil weak, especially in supervision field. Second, externally (from the company) there are obstacles in the form of a) the level of obedience with The Labor Law is still low, due to ASN supervision which is still weak; b) most of company have not managed profesionally; c) paying the decent wages above the minimum level, is considered give harm to the company. In fact, paying the high wage will increase the productivity of the company; and d) cost or company's expenses that are not clear about 20 percent, as a result of the lackness of management of the company.

It should be underlined that the relationship between workers and entrepreneurs not only about the legal relationship, but also social relationship. Both are one family in wide mean-

18 Zulkarnain Ibrahim, "Eksistensi Hukum Pengupahan Yang Layak Berdasarkan Keadilan Substantif”, op. cit., page 354. 
ing, in the sense of brothers on the basis of nationality and homeland Indonesia. Life choice and way of life make wokers and entrep-reneurs realize the different professions, so that one is a worker and the other is a entrepreneur. But both in doing the profesions obey with the norms of labor law. Because of that, the principles of decent wages can guarantee the aim of law in general, they are legal certainty, justice and expediency.

\section{Conclusion}

The principle of decent wages is one of the fundamental principle for workers, with the goal for workers so they can have prosper life with their family. The principle of decent wages in 1945 Constitution and The Labor Law have to be implemented in national development in the field of labor by setting and arrange Labor Planning, Labor Information, and Job Training that held in BLK or Disnakertrans in every Povince or Regency/City. Trained labor and gradute BLK, with the policy of Menakertrans have to get first priority to work in company according to their expertise.

Profesional labor as the result of job training will increase the productivity and profit of company. Positive impact for the labors, they will receive decent wages to make welfare life for themselves and their families and they can life with dignity and respect in society. Thus the principle of decent wage can be im-plemented to reach the aim of labor law, they are: legal certainty, justice and expediency.

\section{References}

Aviliani. Biaya Tenaga Kerja di Indonesia, Makalah Seminar Nasional "Forum Konsolidasi Dewan Pengupahan se Indonesia". Jakarta. 3-5 September 2013;

Budijanto, Oki Wahju. “Evaluasi terhadap Peran Satuan Pamong Praja dalam Perlindungan HAM bagi Masyarakat". Jurnal HAM, Vol. 3 No 2 December 2012. Jakarta: Balitbang HAM Kementerian Hukum dan HAM;

Charda S, Ujang. "Perlindungan Hukum Ketenagakerjaan Terhadap Tenaga Kerja Anak yang Bekerja di luar Hubungan Kerja pada Bentuk Pekerjaan terburuk". Jurnal Syiar,
Vol. XII, No 2. July 2010. Bandung: Faculty of Law Universitas Islam Bandung;

Herbert, William A. et. al. "The Impact of Emerging Technologies in the Workplace: Who's Watching The Man (Who's Watching Me) ?". Law Journal, Vol. 25, 2009. Hofstra Labor \& Employment;

Hernawan, Ari. "Keseimbangan Hak dan Kewajiban Pekerja dan Pengusaha dalam Mogok Kerja”. Jurnal Mimbar Hukum, Vol. 24, No 3 October 2012. Yogyakarta: Faculty of Law UGM;

Ibrahim, Zulkarnain. "Eksistensi Hukum Pengupahan Yang Layak Berdasarkan Keadilan Substantif". Jurnal Dinamika Hukum, Vol. 1, No. 3 September 2013. Purwokerto: Faculty of Law Universitas Jenderal Soedirman;

. "Hukum Pengupahan yang Berkeadilan Substantif (Kajian Teoritis Terhadap Teori Upah Teladan)". Jurnal Masalah-Masalah Hukum, Jilid 42 No 2 April 2013. Semarang: Faculty of Law Universitas Diponegoro;

"Sejarah Hukum Ketenagakerjaan: Studi terhadap Pasang Surutnya Keadilan Sosial Pekerja". Jurnal Simbur Cahaya, Vol. XX, No. 51 Mei 2013. Palembang: Faculty of Law Universitas Sriwijaya;

...-..-. "Pengaturan dan Penegakan Hukum Pengupahan". Jurnal Hukum lus Quia lustum, Vol. 22, No.r 4 October 2015. Yogyakarta: Faculty of Law Universitas Islam Indonesia;

Ito, Minoru. "Measures for Supporting Regional Job Creation in Japan". Japan Labor Review, Vol. 5, Number 1. 2008;

Krustiyati, Atik. "Optimalisasi Perlindungan dan Bantuan Hukum Pekerja Migran melalui Promosi Konvensi Pekerja Migran Tahun 2000”. Jurnal Dinamika Hukum, Vol. 13, No 1. Purwokerto: Faculty of Law Universitas JenderalSoedirman;

Nugroho, Okky Chahyo. "Kajian Atas Kasus-Kasus Pelanggaran HAM TKW di Luar Negeri". Jurnal HAM, Vol. 3 No 2 December 2012. Jakarta: Balitbang HAM Kementerian Hukum dan HAM;

Pusat Penelitian. Pengembangan dan Informasi Kemenakertrans. 2013. Naskah Akademik Arah Kebijakan Ketenagakerjaan Tahun 2014-2019. Jakarta: Kemenakertrans;

Randang, Frankiano B. "Kesiapan Tenaga Kerja Indonesia dalam Persaingan dengan 
Tenaga Kerja Asing".Jurnal Ilmiah Hukum Servanda. Vol. 5, Number 1. Januari 2011. Manado: Faculty of Law Universitas Katolik De La Salle;

Sefriani."Perlindungan HAM Buruh Migran tak berdokumen Berdasarkan Hukum Perdagangan dan Hukum HAM Internasional" Jurnal Dinamika Hukum. Vol. 13, Number 2. May 2013 Edition. Purwokerto: Faculty of Law Universitas Jenderal Soedirman;
Utomo,St. Laksanto. "Permasalahan Outsourcing dalam Sistem Ke-tenagakerjaan di Indonesia”. Jurnal Lex Publica. Vol. 1 Number 1. Januari 2014. Jakarta: Faculty of Law Usahid;

Wijayanti, Asri. 2009. Hukum Ketenagakerjaan Pasca Reformasi. Jakarta: Sinar Grafika. 